\title{
THE TALE OF THE FOUR
}

\section{DERVISHES: THE FIRST URDU \\ ROMANCE TRANSLATED \\ INTO MALAY}

\author{
(Cetra Empat Orang Fakir: Roman Urdu yang Pertama \\ Diterjemahkan ke dalam Bahasa Melayu)
}

Vladimir Braginsky

School of Oriental and African Studies (SOAS), University of London, United Kingdom.

\begin{abstract}
The piece investigated in this article, entitled Cetra Empat Orang Fakir (The Tale of The Four Dervishes) and preserved in the unique manuscript Q $11.4 \mathrm{~A} / 27$ in the National Library of Singapore, allows us to reconsider. It was translated in 1846 and, despite the claim of the translator, cannot be traced to a Persian original. In fact, it is a rendition of Bagh-o-bahar (Garden and Spring, 1802) by the outstanding Urdu writer Mir Amman. Thus, The Tale of The Four Dervishes is the first Malay translation of an Urdu romance. This article investigates information about the translator of Bagh-o-bahar, a Jawi Peranakan named Mahmud bin Sayid Mu'alim, and his socio-cultural environment. It also provides the reader with the content of the Cetra and discusses the strategies of translation used by Mahmud and a combination of old and new features in his work. Even if not without caveats, the findings of this article can also be extrapolated to the lesser-documented literary pieces of the first wave of Islamicate India's influence ${ }^{2}$.

Keywords: Islamicate India, traditional Malay literature, Persian, Urdu, Mir Amman, Bagh-o-bahar, The Tale of The Four Dervishes (TFD), Jawi Peranakan, Mahmud bin Sayid Mu'alim, translation strategies
\end{abstract}




\section{Abstrak}

Naskhah yang dikaji dalam makalah ini bertajuk Cetra Empat Orang Fakir dan tersimpan di National Library of Singapore. Manuskrip unik yang ditandai manuskrip $Q$ 11.4A/27, menunjukkan tarikh pengenalan tersebut perlu dipertimbangkan semula. Manuskrip ini bertarikh tahun 1846, dan penterjemah mendakwa karya asalnya ialah karya sastera Parsi. Namun, karya sastera sebegini tidak terdapat dalam sastera Parsi. Sebaliknya, Cetra Empat Orang Fakir jelas merupakan terjemahan Bagh-o-bahar (Taman dan Musim Bunga, 1802) oleh Mir Amman, penulis Urdu yang unggul. Oleh itu, Cetra Empat Orang Fakir ialah terjemahan pertama Roman Urdu dalam bahasa Melayu. Makalah ini mengkaji maklumat penterjemah karya Bagho-bahar, seorang Jawi Peranakan bernama Mahmud bin Sayid Mu'alim, dan persekitaran sosiobudayanya. Makalah ini juga memberikan maklumat kepada pembaca tentang kandungan Cetra dan membincangkan strategi penterjemahan Mahmud, serta kombinasi ciri lama dan baharu yang ada dalam karyanya. Dapatan makalah ini mungkin juga dapat diaplikasikan dalam kajian naskhah sastera India Islam gelombang pertama yang lain, yang masih kurang mendapat perhatian sarjana.

Kata kunci: India zaman Islam, Sastera Melayu Tradisional, Parsi, Urdu, Mir Amman, Bagh-o-bahar, Cetra Empat Orang Fakir, Jawi Peranakan, Mahmud bin Sayid Mu'alim, strategi penterjemahan

\section{STORICO-LITERARY BACKGROUND: TWO WAVES OF LITERARY INFLUENCE FROM ISLAMICATE INDIA IN TRADITIONAL MALAY LITERATURE}

[At that time] my friend Rahman Khan, a descendant of a Hindustani and a Malay, arrived [in Singapore] and brought with him this book of stories extraordinary in their beauty.

(From the preface of the Malay version of The Tale of The Four Dervishes ${ }^{3}$ )

The significance of literary contacts between the Malay world and Islamicate India has so far not been sufficiently assessed in Malay literary scholarship. This assessment, however, is an important (and overdue) task, since these contacts enriched traditional Malay literature with a substantial number of literary works: translations and, more frequently, peculiar reworkings of source texts written in both the Persian language (one of the major literary languages of medieval India) and Indian vernaculars. We can speak of at least two waves of influence from Islamicate India in traditional Malay literature. 
The first wave reached Pasai in the fourteenth century and brought such compositions in Persian as Hikayat-e Muhammad-e Hanafiyah and Qissa-ye Amir-e Hamzah. The influence of this wave, enhanced by close economic, cultural and religious ties between the Malay world and the Empire of the Great Mughals, as well as the Deccan Sultanates of Bijapur and Golconda, continued in Aceh through the sixteenth to the seventeenth centuries. As an outcome, by the mid-seventeenth century, quite a few identical or similar pieces of literature - heroic epics, framed tales (Kalilah va-Dimnah, Hikayat Bayan Budiman [The Tale of the Wise Parrot], Hikayat Bakhtiar [The Tale of Bakhtiar]), and the edifying "mirrors for princes"- enjoyed equal popularity in Mughal India and the Sultanate of Aceh. In the same era, Islamicate India substantially influenced the formation of Malay sufi literature and the genre of Malay love-and-adventure romances. The latter synthesized a constellation of narrative and descriptive motifs from the Hindu-Javanese tradition and Islamicate India, and also represented, not infrequently, sufi allegories (for instance, Hikayat Indraputra, Hikayat Syah Mardan, partly Hikayat Isma Yatim, and some others).

In the seventeenth to eighteenth centuries, Dutch colonial expansion weakened the ties between the Malay Sultanates and Islamicate India, although it could not undermine these completely. Paradoxically, another colonial expansion, by the British, much contributed to the restoration of these disrupted ties, having united India and a part of the Malay world (especially Singapore and Penang) within the framework of the British Empire. Once again, literary contact - to be more specific, the second wave of inspiration from Islamicate India - became an important form of these ties. Just as the first wave, this one brought a wealth of new literature, both narrative and dramatic. Now, however, this literature was composed in Urdu and some other Indian vernaculars, and not in Persian as before.

Needless to say, the socio-political environments of the first and the second wave of Indo-Malay literary ties were different. The cultural background was also rather dissimilar. For instance, in the sphere of literary production, the lithographic press came to replace the chirographic tradition, while histrionic forms influenced by the Victorian theatre (such as the Parsi theatre and wayang bangsawan) began to oust earlier kinds of performance, such as oral storytelling and reading aloud from a book. And yet the cultural situation of nineteenth-century Penang and Singapore was in some way similar to that of Pasai and Melaka in the fourteenth to the early sixteenth century, or Aceh and Johor of the late sixteenth to the seventeenth century: cultural 
life developed in flourishing, cosmopolitan trading ports and contacts with Islamicate India played an extremely important role. In both cases, the ports accommodated a considerable Indian community with their indispensable "halo" of bilingual Indo-Malay mestizo Muslims (Jawi Peranakan) and their great potential as cultural and literary brokers.

In the course of time, a constellation of Indian narratives and plays of the Parsi theatre, such as Gul-i Bakawali, Indar Sabha, Laili Majnun and half a dozen others, were translated into Malay in the form of hikayat, syair or theatrical librettos. ${ }^{4}$ Alongside these fairly free translations, there appeared Malay compositions that preserved only the core and basic motifs of Urdu plots and were supplemented so much by local elements that they can be considered original pieces of Malay literature (for instance, Hikayat Ganja Mara [Braginsky \& Suvorova, 2007, pp. 118, 143-145]).

The earliest Malay works in the second wave of influence from Islamicate India were composed in the mid-1870s, while the Parsi theatre first appeared in 1862 in Singapore and in the 1870s in Penang. Until recently, this was the generally accepted basis for dating the period when this wave of influence had reached the Malay world. However, the unique manuscript of Qissa-ye char darvesh (Cetra Empat Orang Fakir in Malay, or The Tale of The Four Dervishes), which is kept in the National Library of Singapore under the accession number Q 11.4A/27, allows us to reconsider this date. As we shall see, this manuscript contains a Malay translation of the famous love-andadventure romance Bagh-o-bahar (Garden and Spring) composed in 1802 by the notable Urdu writer Mir Amman (1750-1837) (Faruqi and Pritchett, 1994, p. 143). The translation was completed on 26 November 1846 and copied by 25 April $1847 .{ }^{5}$ This is then the earliest known example of the Malay rendition of an Urdu text, which, in addition, is not related to Parsi theatre. The study of this manuscript, to which we turn now, can shed new light on the beginning of the second stage of literary contact between Islamicate India and the Malay world and the strategies of translation characteristic of the Jawi Peranakan literati of that time.

\section{TRANSLATOR'S PREFACE}

The sinful and negligent mendicant Mahmud bin Sayid Mu'alim, a native of Malacca, tells that at some time and a certain era, he was engaged in mercantile affairs in the city of Singapore [...]

(From the preface of the Malay version of The Tale of The Four Dervishes) 
The MS of the Malay version of The Tale of The Four Dervishes (henceforth referred to as $T F D$ ) begins with a preface that contains a doxology, some information on the original of the translated piece and its translator, a history of the translation, the date of its composition in the form of a chronogram, and a request to correct errors in the translation, addressed to the readers, so that "having received an appropriate expression, this work will benefit all the servants of God who will read it" (MS, p. 1) (for the Malay text of this preface, see Appendix 1). Fairly detailed and extensive in terms of traditional Malay literature, the preface of TFD is worthy of thorough examination. However, for the purposes of this article, I shall only deal with a few of its aspects.

The translator of TFD, Mahmud bin Sayid Mu'alim, informs the reader that he hails from Melaka (anak Melaka). The note of the copyist, Ismail bin Ali, adds to this that the complete name of the translator is Mahmud bin Sayid Mu'alim bin Arsyad Marikan and that his father demised (...bin Almarhum Mu'alim ...) by the time of the MS's copying. The Malaccan origin and the family name Marikan-Tamil in its roots and not infrequently encountered in Malaysia and Singapore - allow us to assume that Mahmud, just as the later translators from Urdu (for instance, Syaikh Muhammad Ali bin Ghulam Husain al-Hindi, Datuk Saudagar Putih, et al.) was a Jawi Peranakan. Since Mahmud received the Urdu original of TFD while staying in Singapore on some commercial business, he may have been a merchant. According to the text, this original was brought to Singapore by another Jawi Peranakan (TFD, p. 1: peranakan orang Hindustan), Rahman Khan. He also helped his friend Mahmud, who did not have enough experience in writing literary Malay (lughat Melayu Jawah [Jawi?]), to translate the composition that had captivated him so much. All these facts allow us to get some idea of the socio-cultural milieu from which TFD originated.

In his preface, Mahmud bin Sayid Mu'alim also repeats a few times that he translated TFD from Persian (dipindahkan daripada bahasa Parsi). Although the name of the author of the Persian source text is not mentioned in the preface of the work, in the work itself this source text is attributed to the great Indo-Persian poet Amir Khusrau Dehlavi (1253-1325) again and again. ${ }^{6}$ It is true that there are several Persian versions of TFD, of which at least one was composed in the nineteenth century, while the rest date back to the seventeenth and eighteenth century. Besides, according to the tradition conveyed by Mir Amman, TFD was narrated by Amir Khusrau to his sufi master, Nizam al-Din Auliyya (1238-1325), the celebrated sufi sheikh of the Chishtiyya brotherhood, in order to entertain him during his illness. 
After his recovery, the sheikh pronounced the following benediction: "That whoever will hear this tale, will, with the blessing of God, remain in health" (Forbes, 1857, p. 3).

However that may have been, Mahmud bin Sayid Mu'alim's statement that he translated TFD from Persian provokes serious doubt. Leaving aside the debatable problem of Amir Khusrau's authorship (see Pritchett, 2005, pp. $\left.1-2^{7}\right)$, we can note that two important peculiarities contrast Persian versions of TFD, which predate the nineteenth century, to Urdu versions. Firstly, those Persian versions do not mention Amir Khusrau as their author (Pritchett, 2005, p. 2). Secondly, the successions of stories in the Urdu and Persian versions of TFD are different: The second dervish's story of the Persian versions is told by the third dervish in the Urdu versions, while the third dervish's story of the Persian versions is told by the second dervish in the Urdu versions. In other words, in the Persian and Urdu versions, the stories of the second and the third dervish exchange positions (Zograf, 1962a, p. 13). ${ }^{8}$ These two easily comparable features show that none of the pre-nineteenth century Persian versions of TFD could have been the source text of Mahmud bin Sayid Mu'alim's Malay translation. In his translation, Amir Khusrau is repeatedly mentioned as the author of $T F D$, and the stories of the second and the third dervish follow the order of the Urdu versions.

It is also hardly possible that the Persian version of TFD composed in 1802 by the Indian author Muhammad 'Ivaz Zarrin could have served as the source text of the Malay translation. As Abdul Haq, a great connoisseur of Urdu literature, remarks: "In his [Zarrin's] work, the qissahs are given very briefly; the situations are just the same" (Pritchett, 2005, pp. 24-25). Contrary to Zarrin's version, in Mahmud's translation all the qissahs (stories) are extensive and detailed narratives, with the majority of these details, as we shall see, also occurring in the Urdu version by Mir Amman.

Therefore, the Malay translation of TFD is traceable not to Persian but to Urdu versions of this literary piece, of which there were at least two. One of them, entitled Nau tarz-e murassa' (A New Style of Adornment), was composed around 1775 by Mir Muhammad Husain 'Ata Khan, better known by his pen name, Tahsin. The language of this version, according to Abdul Haq, "is extremely colourful, and filled with similes and metaphors from head to foot. So much so that while reading, at some points one's mind begins to feel nauseated. [...] The style of the language is archaic and it is overflowing with Persian constructions and words" (Pritchett, 2005, pp. 14-15). The second version is the classic Bagh-o-bahar composed by Mir Amman in 1802 in simple, clear and idiomatic language, the style 
of which is eloquent and elegant. As Abdul Haq notes, "There is neither inappropriate prolongation, nor useless verbiage [in this book]. To write in simple language is extremely difficult. [...] To combine simplicity with eloquence and to maintain an enjoyable style is a great achievement [of Mir Amman]" (Pritchett, 2005, p. 16). ${ }^{9}$

Mahmud bin Sayid Mu'alim's translation does not reveal even accidental echoes of the excessively metaphoric, artificial style of Tahsin's Nau tarz-e murassa', let alone any attempt to somehow reproduce it. This, by itself, puts into question the possibility that this work could be the source of his translation. Moreover, judging by the fact that even insignificant complications in the imagery of descriptive passages in Mir Amman's work - the actual source of the translation under discussion, as I shall try to argue - presented insurmountable obstacles for Mahmud, it is unlikely that he was competent enough to translate a text as difficult as Tahsin's.

A number of facts support the assumption that Mahmud bin Sayid $\mathrm{Mu}$ 'alim rendered none other than Mir Amman's Bagh-o-bahar into Malay. First of all, the Malay version of TFD contains all the episodes of this work in Urdu, which follow one another exactly in the order of the latter. Narrative passages of these episodes in the Malay translation generally contain most of the sentences of which they consist in Bagh-o-bahar. Here is only one example of how closely the Malay translation corresponds to Mir Amman's text, its suggested source ${ }^{10}$ :

\section{Bagh-o-bahar by Mir Amman (Forbes, 1857, pp. 113-114)}

One day, the moment the morning appeared, all the inhabitants of the city, little and great, young and old, poor and rich, issued forth. They went out and assembled on a plain; the king of the country went there also, mounted on horseback, and surrounded by his nobles; then they all formed a regular line, and stood still. I also stood among them to see the strange sight, for it clearly appeared that they were waiting for [the arrival of] some one.

In an hour's time a beautiful young man, of an angelic form, about fifteen or sixteen years of age, uttering a loud noise, and foaming at the mouth, and mounted on a dun bull, holding something in one hand,
(Malay version of The Tale of the Four Dervishes (TFD, pp. 88-89)

One day, all the townsfolk, little and great, old and young, went out of the city. Outside the city there was a very spacious plain, and all the townsfolk headed for this plain, assembled on it and lined up in rows. The king of that city and his grandees were also present there. So, I joined that great multitude of people.

Meanwhile, from the direction of the nearby forest, there appeared a young man of rare handsomeness, foaming at the mouth. He was thirteen or fourteen years of age, looked like a child of a great king and mounted a dun bull. Having approached that multitude of Allah's 


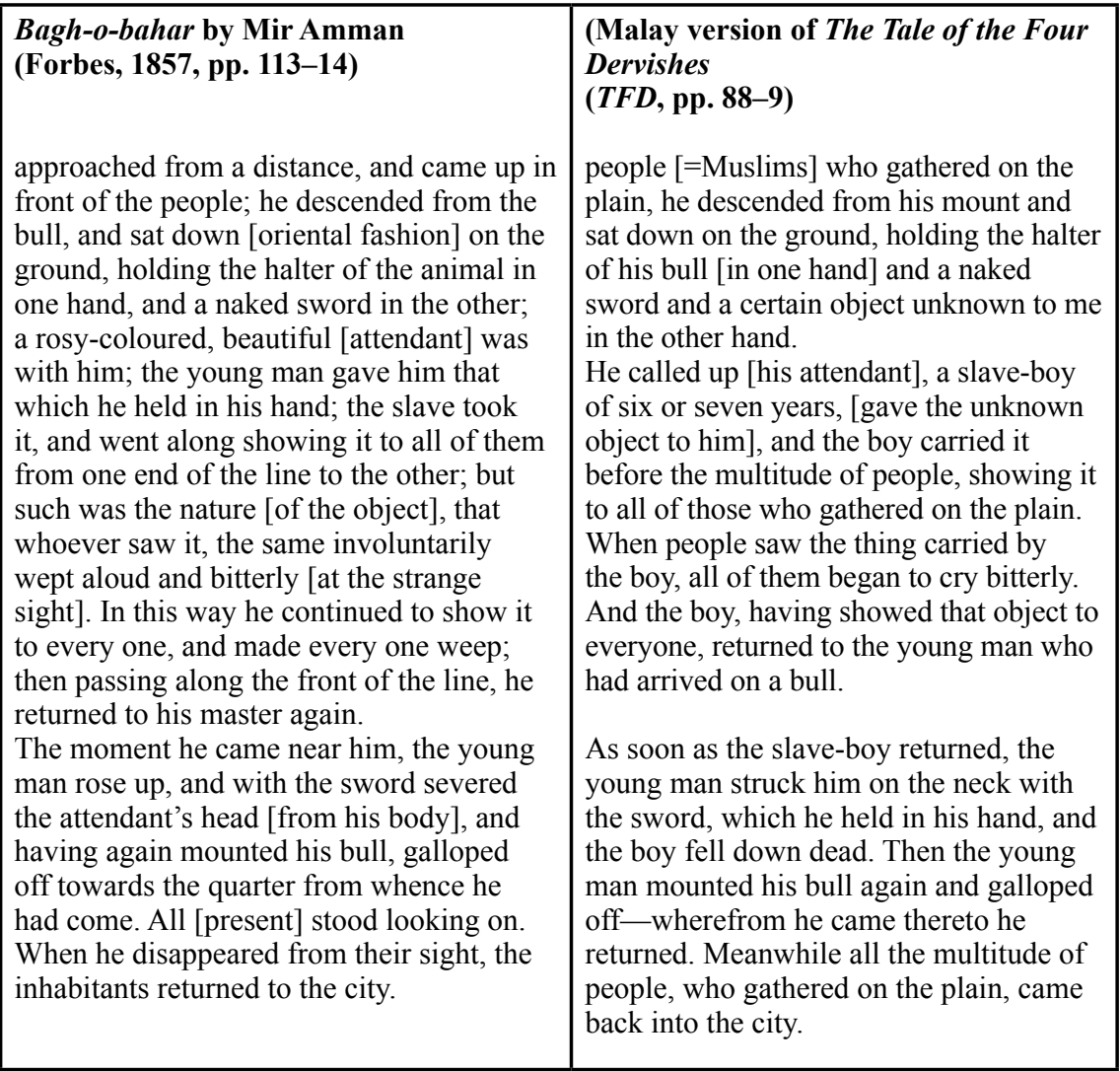

Roughly the same degree of closeness to Bagh-o-bahar is characteristic of the majority of the narrative passages in the Malay translation of TFD. Interestingly, all the passages of Bagh-o-bahar that Abdul Haq considers particularly typical of Mir Amman's language and manner of writing occur in TFD and contain most of the expressive details to which 'Abdul Haq draws the reader's attention (Pritchett, 2005, pp. 17-20). ${ }^{11}$

Alongside the close correspondence between Mahmud's translation and Bagh-o-bahar, two more specific, and therefore more convincing, features are indicative of the fact that Mir Amman's work does represent the original of the Malay TFD. One of them is the rendition, sometimes rather awkward, of Mir Amman's verses from Bagh-o-bahar that occur in TFD (see, for instance, pp. 11, 64, 97, 125). Here are some examples: 


\section{Bagh-o-bahar by Mir Amman (Forbes, 1857, 29, 93, 148)}

Beloved of God, turn towards me, and hear this helpless one's narrative. / Hear what has passed over my head with attentive ears. / Hear how Providence has raised and depressed me. / I am going to relate whatever misfortunes I have suffered; hear the whole narrative.

O friends, to this faqir's story listen a little;/ I will tell it to you,--from first to the last, listen; / Whose cure no physician can perform; /

My pain is far beyond remedy,--listen.

Why should not she of the arched eyebrows come [to my house], / She for whose sake I have fasted for forty days.
Malay version of The Tale of the Four Dervishes (TFD:11, 64, 125)

O servants of God, hearken with full attention, / and give your ears to the most attentive listening. / $\mathrm{O}$ [my] lords, listen to the story, which this dervish [=I, me] will tell you of what he endured and heard and saw. / He will narrate the story of his experiences - the head of this story is below and its feet are above [i.e., the story of how misfortunes turned his life upside down].

And now, [O my] lords, please hearken a story of this dervish, / which I shall tell you in all details from the beginning to the end. / It relates of my condition similar to those of the person struck by a severe disease, / about which he can complain to no one. / Even if great sages or outstanding physicians wish to cure my disease, / they would never succeed. For the reason of my yielding to weaknesses of my heart, / I fell sick of this terrible disease.

You, whose eyebrows are similar to curved spurs [of a fighting cock], why don't you come here? / Whereas it is because of you that I have fasted for forty days.

Another feature is the appearance of colloquial expressions, so characteristic of Mir Amman's idiomatic language, in Mahmud's translation. Some of them - for instance the expression "the frog caught cold", which implies something absurd and is "to ridicule the extravagant idea of a merchant's son presuming to be in love with a princess" (Forbes, 1857, p. 61, n. 1) - are rendered rather whimsically, whereas the others are translated fairly precisely, though not without a certain Malay colouring: 


\begin{tabular}{|l|l|}
\hline $\begin{array}{l}\text { Bagh-o-bahar by Mir Amman } \\
\text { (Forbes, 1857:61, 260) }\end{array}$ & $\begin{array}{l}\text { Malay version of The Tale of the Four } \\
\text { Dervishes } \\
\text { (TFD:28, 206) }\end{array}$ \\
$\begin{array}{l}\text { On hearing these words, she was greatly } \\
\text { offended, and frowning with anger, she } \\
\text { exclaimed, 'Very fine indeed! What, thou } \\
\text { art my lover! Has the frog then caught } \\
\text { cold?'. }\end{array}$ & $\begin{array}{l}\text { Then her moon-like countenance } \\
\text { darkened and became sullen. Having } \\
\text { frowned with anger, the princess said: } \\
\text { 'How nice! It means that all this time } \\
\text { there and drank your wine here. }\end{array}$ \\
$\begin{array}{l}\text { you have been in love with me. Old men } \\
\text { used to say: 'The place of a frog is in the } \\
\text { water'. Yet, now, listening to you, I hear } \\
\text { the frog saying, as it were: 'Living in the } \\
\text { water, I seem to have drowned'. } \\
\text { [Be quick], as if you ate your rice in the } \\
\text { garden and washed your hands [after } \\
\text { eating] here. }\end{array}$ \\
\hline
\end{tabular}

Finally, one more argument in favour of Bagh-o-bahar as the source of the Malay translation is that Tahsin's Nau tarz-e murassa' was a marginal work that was difficult to obtain. In contrast, Mir Amman's much more popular piece had already been lithographed six times before 1846, the year of the Malay version of TFD (Grierson, 1903, p. 32). It was issued in Calcutta in 1804, 1813, 1824 and 1834, in Cawnpore in 1833 and, particularly interestingly, in Madras (Tamilnadu) in 1840, only six years before the date of the Malay translation. With all this in mind, it seems safe enough to argue that the text that Mahmud bin Sayid Mu'alim translated into Malay with the assistance of his friend Rahman Khan was none other than Bagh-o-bahar.

Another remarkable feature of the preface of the Malay version of TFD is that it contains the date of the translation in the form of a chronogram. While quite usual in the literature of the Middle East and Islamicate India, chronograms rarely occur in traditional Malay texts. As an example, I can quote only a passage from Taj as-salatin, in which the word ghaib stands for 1603, the year of its composition (Marre, 1878, p. 13, nn. 1-2). The chronogram in TFD is the Arabic word combination bi-sargh. Since, according to the abjad numerical system, the value of letter $b a$ is $2, \sin$ is $60, r a$ is 200 and ghain is 1000 , the year in question is $1262 \mathrm{AH}$ (corresponding to $1846 \mathrm{CE}$ ).

Chronograms not infrequently contained hints and allusions of various kinds. For instance, the chronogram Jahangir (289) az (8) jahan (59) raft (680), which literally means "World conqueror left the world", points to 1036 AH, the year of the Emperor Jahangir's death (Farooqi, 2003, p. 150). What draws attention to TFD's chronogram bi-sargh, which means "on an 
offshoot [of the vine]" or "thanks to an offshoot [of the vine]", is its garden associations; moreover, offshoots appear on vines in the springtime. Could, consciously or unconsciously, the title Bagh-o-bahar meaning 'Garden and Spring', which is at the same time the chronogram for $1217 \mathrm{AH}(1802 \mathrm{CE})$, the year of that book's composition, have brought forth these associations in Mahmud bin Sayid Mu'alim's mind? On the other hand, Mahmud's chronogram could allude to the fact that his translation 'sits', as it were, on an 'offshoot' (Mir Amman's book) of the 'vine' (Amir Khusrau's alleged original of TFD) or that his translation came to existence thanks to this 'offshoot'. Both interpretations are plausible. In both cases, an allusion to Bagh-o-bahar cannot be excluded.

However, what could force Mahmud to conceal the real source of his translation? There may have been several reasons for this. One of them was that the original author of TFD had, after all, been Amir Khusrau, who composed it in Persian. No matter whether this attribution is correct or otherwise - from the point of view of modern scholarship-Mahmud undoubtedly believed this, although, paradoxically, he found this attribution not in Persian versions of TFD (in which it is absent), but in the work of that same Mir Amman. Another reason was the high authority of Persian works in traditional Malay literature, which at the time of Mahmud's translation surpassed by far that of pieces in Urdu.

Last but not least, religious considerations may have played an important, if not decisive, role in the concealment of the source author's name. The point is that Mir Amman's creation had a distinct 'smell' of Shi' ism, (berbau Syiah, as traditional Malay literati would have put it): not only did the introduction to Bagh-o-bahar contain a long eulogy addressed to the twelve imams, but also none other than Ali Murtaza saves the life of each protagonist at the moment of his utter desperation. It goes without saying that these features of Mir Amman's narrative are removed from the Malay translation (Ali, for instance, is transformed into a nameless, mysterious prince). Even the more subtle Shi 'ite motifs in Mir Amman's book appear to have worried Mahmud bin Sayid Mu'alim. It is hardly accidental that in the beginning of his preface to TFD he pleads Allah "to protect us from unbelief and treacherous (or rather apostatical) words" and in its ending he asks the readers to improve everything in his book that "is unacceptable in terms of the law (syara") of our Prophet" (TFD, p. 1).

With all this in mind, it is little wonder that Mahmud preferred to attribute $T F D$ to a great Persian poet, not to a less-known Urdu writer and 
Shi'ite. Both Mahmud's Sunnite piety and his striving for the success of the translation with a Malay audience required this attribution. Curiously enough, with this false attribution, Mahmud seems to have followed the example of Mir Amman himself, who had also presented his Bagh-o-bahar as a translation of the Persian work by Amir Khusrau and had chosen to ignore Tahsin, the genuine author of the Urdu source text that he reworked (Pritchett, 2005, pp. 2-14).

\section{CONTENTS OF THE FOUR DERVISHES' STORIES}

This narrative includes the stories originally told by saints and wise men and those who turned their back to the world ... and it consists of five tales.

(From the preface of the Malay version of The Tale of The Four Dervishes)

After a discussion of some issues pertaining the preface of $T F D$, it is now time to get acquainted with the content of TFD more closely. Similar to many love-and-adventure narratives, Urdu and Malay alike, the hikayat begins with the story of a childless king, in this case the King of Rum (Turkey) Azadbakht (pp. 2-11). ${ }^{12}$

One day, looking in the mirror, the king notices a grey strand in his hair. He meditates on the transitoriness of the world and wishes to leave his realm in order to spend the rest of his life in prayer and deeds of piety. However, his wise vizier Khiradmand persuades the king that he should perform his royal duties in the daytime and serve God at night. One night, the king sets out to a cemetery in the hope of meeting dervishes, who reject the material world, and receiving their instructions. Having approached the cemetery, he notices four dervishes, who while away the night telling tales about what happened to them in their life. Azadbakht hides himself and listens to their stories.

The first dervish tells the story (pp. 12-41) of how his father, a merchant from Yemen, left him a great fortune. Having thoughtlessly wasted his inheritance, the merchant's son pleads with his sister to help him. He buys various goods with her money and departs for a trading trip to Dimasyk (Damascus). While spending the night at the closed gates of Dimasyk, he sees how someone lowers a chest from the city wall and finds a badly wounded, beautiful girl in the chest. The merchant's son fetches a physician to cure the girl and spends all his money taking care of her. He falls head over heels in love with the beautiful girl, who, however, remains unattainable to him 
and prohibits the merchant's son from asking her any questions about her past. When the young merchant's money is exhausted, the girl sends him to a certain Siti Bahar, who, without a question, gives him a lot of gold.

The beautiful girl insists that the merchant's son should become friends with a young jeweller, Yusuf. Yusuf invites him to his luxurious house, arranges a sumptuous feast and acquaints the young merchant with his lover, who is exceptionally ugly. The merchant's beloved tells him that he, in his turn, should invite Yusuf and throw a banquet even more splendid than that of the jeweller. At the banquet, the merchant's son gets drunk and loses consciousness. The next morning, when he comes to, he finds the decapitated bodies of Yusuf and his ugly lover and learns that his beloved has deserted him. The young merchant eventually finds the girl, who is infuriated by his reckless behaviour at the banquet. Yet, in the end, she forgives and marries him.

After a lot of coaxing, the merchant's wife agrees to tell him her story (pp. 41-58). She is the princess of Dimasyk who fell in love with her handsome servant Yusuf. Playing on her passion for him, the servant became rich and famous in their city and persuaded the princess to buy a beautiful garden and a female slave for him. Once, wishing to admire the garden, the princess set off to pay Yusuf a visit. Together with his ugly slave, Yusuf made her drunk, injured her with his sword and, considering the princess dead, lowered her in a chest from the city wall. The merchant's son saved the princess's life and helped her to take revenge on the treacherous servant, even though he did not know that.

The princess does not want to stay in Dimasyk any longer and leaves the city with her husband. After a long journey, they come to the sea and the merchant's son sets off in search of a boat. However, when he returns, he does not find the princess on the seashore. In vain the merchant's son looks for her everywhere. His desperation is so great that he is ready to commit suicide, but, at this moment, a mysterious rider who is wrapped in a green cloak and whose face is covered appears before him. He dissuades the merchant's son from suicide and advises him to go to Rum to King Azadbakht. There he will meet three dervishes and will reach the fulfilment of his desire.

The second dervish begins his story (pp. 64-128) and relates that he was born as a prince of Fars (Persia). From his early years he was fond of tales about people who had managed to achieve eternal fame, particularly those about the extraordinarily generous Hatim Ta'i (pp. 66-72). After his father died and he became the king, he decided to become famous for equal generosity. However, a dervish, who annoyed him by getting alms forty 
times in a row in one and the same day, explained to the prince that he was still very far from genuine generosity, of which the only possessor is the princess of Basra.

The prince of Fars sets off to Basra in order to meet the princess. However, before their meeting, the princess's servant, Bahrawar, tells him about strange events in the city of Nimroz. Every month, all the people of the city gather on a broad plain. The prince of Nimroz comes to the plain on the back of a dun bull, and kills his young slave. Afterwards he leaves the plain and, with loud groans and moans, disappears in the forest (pp. 87-89). When the prince of Fars meets the princess of Basra, he expresses his admiration for her generosity and beauty. A lady-in-waiting of the princess tells him that the princess's father unjustly expelled her from the palace, but, by the mercy of God, she found a treasury with inexhaustible riches (pp. 95-106). The prince offers the princess his hand and heart, and she agrees to marry him, if he learns the secret of the prince of Nimroz.

The prince of Fars arrives in Nimroz and, at great risk to his own life, persuades the prince of Nimroz to tell him his story (pp. 111-127). Astrologers foretold that at the age of fourteen, a disaster might befall the prince. Therefore, his parents hid him in an underground chamber, where he saw no sunlight. However, no one can escape fate. Once, a throne on which a beautiful peri was seated descended into the chamber through its dome. The prince and the peri fell in love with each other, but the peri's father, the king of jinns, separated them. Distraught with grief, the prince fell seriously ill, and his parents sent him to a great yogi to be cured. There he took hold of the book containing the greatest name of Allah and, with its help, summoned the king of jinns. The poor enamoured prince asked the king to leave the princess of peris with him and promised that he would not touch her. However, he failed to keep his promise and the jinns took away his magic book and separated him from his beloved again. Since then, every month, he rides on the bull, into which he has turned one of the jinns, to the plain and performs strange actions, so that everyone can see how deeply he suffers.

The prince of Fars, who feels compassion for him, promises his help to the enamoured prince and sets off in search of the peri. However, he fails to find her and is ready to commit suicide in desperation. At that moment, the same green horseman appears, stops the prince and advises him that he should go to Rum.

Meanwhile, dawn breaks. Azadbakht returns to his palace and sends a courtier to bring the dervishes. The king tells them that on the previous 
night, he listened to the stories of two of them and now wishes to know the adventures of the two others. To encourage the dervishes, the king suggests telling them his own story first.

One day, an Iraqi merchant arrives in Rum and presents a very big ruby to him. Azadbakht is extremely proud of the ruby and likes to boast of it but his wise vizier says that this jewel, like all other worldly riches, is not deserving of praise. Moreover, he says, a merchant from Nishapur has embellished the collar of his dog with twelve rubies bigger than the king's. Azadbakht calls the vizier a liar and throws him in the dungeon. In the guise of a young male trader, the vizier's daughter sets off to Nishapur in order to find the merchant who owns the dog to prove that her father told the truth. The 'young trader' charms the merchant and persuades him to go with 'him' to Rum. The "young trader" and the Nishapur merchant arrive in Rum. The merchant brings the dog and two of his own brothers, who are put into cages, with him. Infuriated that the merchant keeps human beings in cages but does everything to please his dog, Azadbakht wants to execute him. To save his own life, the merchant has to explain his strange behaviour, for which he has come to be called "dog-worshipper", and tell the king his story (pp. 144-195).

The merchant tells the king that when his father died, the merchant's brothers stripped him of his share of the inheritance and tried to kill him many times. However, each time his brothers tried to kill him, the merchant's faithful and extraordinarily clever dog managed to save the life of its master. Having lost all his possessions, the merchant found himself in a new country, where he experienced many amazing adventures, such as his liberation from the horrible "dungeon of the Prophet Sulaiman", about which his rescuer, the princess of Iraq, narrates a story (pp. 155-157).

Eventually, thanks to the mercy of Allah, to whom the merchant is as loyal as his dog is loyal to him, and to whose faith he converts a few princess-idol-worshippers, the merchant becomes rich again. Afterwards, he learns that his evil brothers have committed another crime and are in trouble again. He rescues them, and the whole situation repeats itself. In the end, the merchant puts his incorrigible brothers in cages but surrounds the faithful dog with comfort and luxury.

Azadbakht approves of the merchant's actions and asks him about the origin of his enormous rubies. The merchant replies that once he met a young man who presented him with these rubies and who told him the following story (pp. 180-193): after a shipwreck, the young man found himself in a 
magical city, where there was an abundance of such jewels. He was buried alive in that city but managed to escape together with his beloved, and took the rubies with him. The story of the merchant convinces the king that his vizier told him the truth. He releases the vizier and marries the vizier's intelligent daughter to the merchant.

When Azadbakht finishes his narrative, the third dervish agrees to relate the story of his misfortunes (pp. 198-225). In fact, he is the prince of Ajam. One day, he goes hunting, chases a very beautiful doe, wounds her in the leg and finds himself in the house of an old man, Niman Sayah, whose pet is the wounded doe. The old man curses the prince and, although he forgives him later, the prince is doomed to suffer from pangs of love. In the house of Niman Sayah, the prince finds a statue of an incomparably charming girl and passionately falls in love with her. The old man tells the story of this statue (pp. 202-210). It is the statue of the princess of Farang with whom he is hopelessly in love. The prince of Ajam departs to Farang and, after a number of adventures, unites with the princess with the help of the powerful warrior Bihzad Khan. However, when, on the way back, the pair of lovers crosses a river, the princess of Farang suddenly disappears in the waves. Because of his grief the prince nearly loses his mind, dresses up as a dervish and begins wandering over jungles and mountains. He wishes to commit suicide but the green horseman keeps him from this reckless step and sends him to Rum.

The time of the fourth dervish's story comes (pp. 225-251). He was the prince of Cin (China). Before his father, the king, died, he entrusted the prince, his only son, to his brother's care. However, the treacherous uncle only looks for the opportunity to kill the prince and to usurp the throne. A loyal servant, Mubarak, rescues the prince and brings him to his father's friend, a king of jinns named Malik Sadik. Malik Sadik is ready to help the prince get back his realm, provided the prince finds and brings him the beautiful girl which he has seen depicted in a portrait. However, the king of jinns repeatedly warns the prince that, in case of treachery or an attempt to get the girl for himself, he will be severely punished. The prince and Mubarak set out in search of the girl but when they finally find her, her father tells them the sad story of his daughter (pp. 239-244). Anyone who wishes to marry her dies in a mysterious manner. This has happened to the son of the king whom the girl's father serves as a courtier. The prince falls in love with the girl and, although he brings her to Malik Sadik, he does not want to give her to the king of jinns. With the help of a ruse, Mubarak tries to save the girl 
from Malik Sadik. However, the latter uncovers the ruse, attacks the prince, gains victory, and takes the girl away from him. In desperation, the prince sets off on wanderings. He is ready to throw himself from a high mountain when the same green rider stops him and sends him to Rum.

When the fourth dervish finishes his tale, King Azadbakht suddenly learns that one of his wives has just borne him a son. Overwhelmed with joy, the king orders a great feast. With the help of another king of jinns, Malik Syahpal, Azadbakht marries off all the separated lovers: the merchant's son from Yemen to the princess of Dimasyk, the prince of Fars to the princess of Basra, the prince of Ajam to the princess of Farang, the prince of Nimroz to the princess of jinns, and the prince of China to the daughter of the courtier who was kidnapped by Malik Sadik. Everyone thus happily achieves the fulfilment of his or her desire.

\section{STRATEGIES OF TRANSLATION}

And love and passion for these stories entered my soul ... so that I asked him to help me in their translation.

(From the preface of the Malay version of The Tale of The Four Dervishes)

While trying to identify the source text of the Malay version of TFD, we have already touched upon some specific features of its translation. Now we shall discuss this issue in more detail.

The principles that Mahmud bin Sayid Mu'alim and his assistant adhered to in their rendering of Mir Amman's work does not differ greatly from those of their predecessors belonging to the first wave of literary influence from Islamicate India, that is, the translators of Persian literary pieces. In both cases, an idiomatic and an unidiomatic rendition of the source text constituted two "poles" of translation strategy. The choice of a particular strategy normally depended on the function which the section to be translated had performed in the source text. Therefore, it was precisely the means to indicate this function that the translator sought in the semantic and stylistic tissue of Malay, the language of the target text.

The idiomatic strategy of translation was usually used for narrative sections of the source text, whereas the unidiomatic strategy was used for its edifying sections that abounded in quotations from the Qur'an and hadith, poetic insertions and all kinds of passages written in a religious, legalistic 
or scholarly manner. In the eyes of the Malay translators, the authority of those quotations and passages, or their great importance within the context of the work - or both - required the reproduction of not only their meaning but also their syntax. Little wonder, therefore, that their attempt to fulfil this contradictory task was fraught with a kind of "translationese", which was "not only distinguished by its clumsiness and its weird constructions, but also by a distinctly deviant use of prepositions" (Brakel, 1975, p. 43). Between these two "poles" of translation strategy lies the whole spectrum of transitional forms, more or less idiomatic or otherwise.

A number of these forms can be found in Mahmud's translation. A considerable, if not greater, part of Bagh-o-bahar's narrative segments are rendered into idiomatic Malay. Once again, just as in the translations of his predecessors of the first wave, Mahmud's idiomatic strategy is based not so much on a word-for-word rendition of the Urdu original as on its sentence-bysentence (or close to sentence-by-sentence) paraphrase in Malay. Inherent in this paraphrase are relatively few additions or omissions, or embellishments added to the source text or skipped over, and slight traces of the source text's vocabulary. A good example of this idiomatic and fairly exact translation is presented by the above-quoted episode about the prince on the dun bull. However, not infrequently, Mahmud's translation of Urdu narrative passages - particularly those combining narration with edification-show different degrees of deviation from the idiomatic strategy. In such cases, Mir Amman's elegantly lucid, concise narration is substantially extended by various explanatory remarks, deliberations intended to enhance didactic overtones of a passage or to add such overtones to it, and sometimes simply by repetitions of words and word combinations rather awkwardly arranged and only leading to the translated passage's long-windedness. The latter is particularly characteristic of the rendition of Mir Amman's verses (see examples on p.8). Self-standing segments in Bagh-o-bahar, these verses in the Malay TFD are occasionally reworked into a part of the character's prose monologue ${ }^{13}$ or integrated into a prose narrative as one of its sentences.

Typical examples of the didactic (and long-winded) amplification of the $T F D$ source text are the examples of those exemplary passages (from Abdul Haq's viewpoint) of Mir Amman's work that occur in Mahmud's translation. The real extent of this amplification becomes clearer if the preceding part of the above passage is also quoted: 


\section{Bagh-o-bahar by Mir Amman} (Forbes, 1857, pp. 32-3)

This mendicant [i.e., the first dervish telling this story] had no sooner reposed himself in [the vacant] seat [of his father] than he was surrounded by fops, coxcombs, 'thiggars and sornars' [parasites], liars and flatterers, who became his favourites and friends. I began to have them constantly in my company. They amused me with the gossip of every place, and every idle, lying tittle tattle; they continued urging me thus: 'In this season of youth, you ought to drink of the choicest wines, and send for beautiful mistresses to participate in the pleasures thereof, and enjoy yourself in their company.'
In short, the evil genius of man is man: my disposition changed from listening constantly [to their pernicious advice.] Wine, dancing, and gaming occupied my time. At last matters came to such a pitch, that, forgetting my commercial concerns, a mania for debauchery and gambling came over me. My servants and companions, when they perceived my careless habits, secreted all they could lay hand on; one might say a systematic plunder took place. No account was kept of the money which was squandered; from whence it came, or where it went:

\section{Malay version of The Tale of the Four Dervishes (TFD, pp. 13-14)}

Some time had passed since I sat down [on my father's seat], and there came a year, and a month, and a day, and an hour, when a misfortune came down upon my head. At that time I was visited by a great multitude of young men from amongst those shameless, boorish and seditious as well as by the envious ones of all kinds. Because of their evil designs, they arrived to make friends with me. And I began to follow their vile advice, and imitate their manners, and thus I fell into the net of those scoundrels.

So, these scoundrels taught me, saying: 'Hey young lord of handsome countenance, what is the use of all these [an illegible word] great riches, if you don't enjoy them while you are young? Why will you wait, [postponing this pleasure]? What is good for us is good for you! [Firstly,] learn to drink wine, and other drinks that evoke love and passion and make you so drunk that you cannot walk straight. It is good for everyone. And secondly, when you want to drink [wine], do not drink alone. [Otherwise] you'll never figure out flavours of the wine and its deliciousness. It is much better if you [drink it] in the company of young beauties. Only then will you comprehend the taste and sweetness of wine and these damsels'.

When I heard [all this], my heart opened up and I experienced great joy. Having listened to their words and exhortations, I did just what they had said. I forgot completely about my business and trade, and never remembered them again. I sold out the countless riches, which my father had left me, without thinking whether the prices were right and whether [my servants] stole from my father's heritage. The wealth left just as it had come.

Countless and limitless possessions were sold out [without counting the price] as if their owner had lost his mind. 


\begin{tabular}{|c|c|}
\hline $\begin{array}{l}\text { Bagh-o-bahar by Mir Amman } \\
\text { (Forbes, 1857, pp. 32-3) }\end{array}$ & $\begin{array}{l}\text { Malay version of The Tale of the Four } \\
\text { Dervishes } \\
\text { (TFD, pp. 13-14) }\end{array}$ \\
\hline $\begin{array}{l}\text { When the wealth comes gratuitously, the } \\
\text { heart has no mercy on it. }\end{array}$ & $\begin{array}{l}\text { So, I stubbornly followed the words of } \\
\text { the Devil instigating man. [In fact,] these } \\
\text { were instigations not of the Devil created } \\
\text { by our Lord, but of people devilish in } \\
\text { character. And yet, the instigations of } \\
\text { these devil-people were sufficient [to lead } \\
\text { me astray]. I did not care of the wealth } \\
\text { that had been left to me by my royal } \\
\text { father. Why? [Because] I did not earn that } \\
\text { wealth through my own labour and did } \\
\text { not procure it myself. Had I earned that } \\
\text { wealth myself, I, no doubt, would not } \\
\text { have spent it in this manner. }{ }^{14}\end{array}$ \\
\hline $\begin{array}{l}\text { Had I possessed even the treasures of } \\
\text { Karun [the rich man, a personification } \\
\text { of wealth], they would not have been } \\
\text { sufficient to supply this vast expenditure. }\end{array}$ & $\begin{array}{l}\text { However, now I realize that even if my } \\
\text { possessions sold at that time had not } \\
\text { been second to the treasures of Karun in } \\
\text { value, they would nevertheless have been } \\
\text { wasted in the twinkling of an eye. } \\
\text { And the storyteller says: 'Hearken to } \\
\text { the admonitions of your brother, take as } \\
\text { much [good] as you can from his words } \\
\text { and use it for [perfecting] your mind and } \\
\text { heart. O my brothers, elder and younger, } \\
\text { hearken the story of the one whose riches } \\
\text { slipped out of his hands'. }\end{array}$ \\
\hline
\end{tabular}

One more reason for changing the source text, which caused its lengthening, was its adaptation to the expectations of the target audience. Such adaptations in Mahmud's rendition of TFD are numerous and can be examined on many levels of their semantics and expression. Here, however, I limit myself to only one example that appears to combine Mahmud's edifying intentions and his striving to meet the audience's tastes and idiosyncrasies. Although stories of two of the dervishes describe their early life as princes, Mir Amman tells next to nothing of their education. Yet, this was likely an issue of great importance for Mahmud bin Sayid Mu'alim. Moreover, traditional Malay literature in general paid sufficient attention to the education of princes. Such compositions as Taj as-salatin, Hikayat Isma Yatim, Hikayat Hang Tuah and Hikayat Aceh — to mention only several works of many — bear witness to this fact. Therefore, the Malay translation of Bagh-o-bahar adds 
narratives, even though highly formulaic, about the educational background of its characters. Here is an example:

\begin{abstract}
Bagh-o-bahar by Mir Amman (Forbes, 1857, p. 251)

[...] my father was king of that country, and had no children except myself. In the season of my youth, I used to play with my companions at chaupar cards, chess, and backgammon; or mounting my horse, I used to enjoy the pleasures of the chase.
\end{abstract}

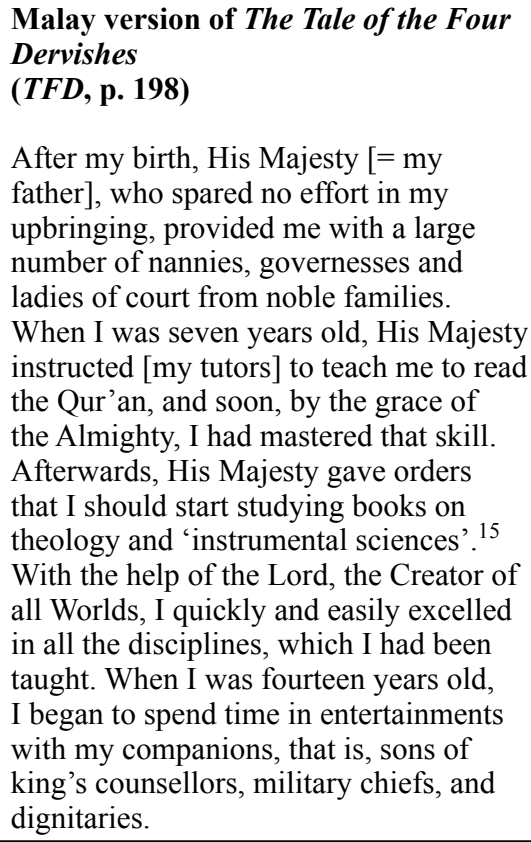

After my birth, His Majesty [ = my father], who spared no effort in my upbringing, provided me with a large number of nannies, governesses and ladies of court from noble families. When I was seven years old, His Majesty instructed [my tutors] to teach me to read the Qur'an, and soon, by the grace of the Almighty, I had mastered that skill. Afterwards, His Majesty gave orders that I should start studying books on theology and 'instrumental sciences'. 15 With the help of the Lord, the Creator of all Worlds, I quickly and easily excelled in all the disciplines, which I had been taught. When I was fourteen years old, I began to spend time in entertainments with my companions, that is, sons of king's counsellors, military chiefs, and dignitaries.

In the preface of his translation, Mahmud asks the readers to improve his translation, as, for his traditionally announced "ignorance", he "extended short passages and shortened long passages" of the original. It is true that, like his predecessors and successors, he shortened and even omitted some pieces of Mir Amman's text too difficult for translation or the understanding of the audience and too rhetorically refined or artificial for the Malay literary taste. However, for the reasons discussed above, the "extension of short passages" is by far more prevalent than the "shortening of long ones" in Mahmud's rendering of narrative sections of Bagh-o-bahar. His translation thereof is sufficiently adequate on the whole.

A totally different strategy was chosen by Mahmud for the translation of innumerable descriptions of Mir Amman's book. This is not even so much a strategy of translation or rendition as a strategy of substitution. More often than not, Mahmud replaces Bagh-o-bahar descriptive motifs, exquisite but alien to traditional Malay literature, with their typically Malay versions. We 
can observe this strategy of substitution in the Malay TFD's portrayals of palaces and gardens, female beauty, resplendent garments and ornaments of radiant gems, picturesque ceremonies and marvellous distant lands.

In many cases, Mahmud extends the descriptive passages of Mir Amman, too. For example, in the Urdu original, the story of the fourth dervish only briefly describes the wedding ceremony:

From that day the preparations for the marriage were begun by both parties; and on an auspicious hour, all the qazis and muftis, the learned men and the nobles were convened, and the marriage rites were performed; the bride was carried away with great éclat, and all the ceremonies were finished.

(Forbes, 1857, p. 292)

The Malay translation, which in this case has little in common with its Urdu source text, describes the event at length, completely in the manner of Malay fantastical adventure romances (such as Hikayat Indraputra), using the majority of their stock formulas.

\section{Malay version of The Tale of the Four Dervishes (TFD, pp. 240-241)}

The king gave orders to his counsellors and military chiefs that they should begin wedding celebrations for the princess, which, in accordance with the customs of great kings, were to continue uninterruptedly for forty days and forty nights. And all kinds of feasts, entertainments, competitions in martial arts and dances were to be performed, so that everyone could amuse himself in his own manner.

When forty days and forty nights had passed, the princess was carried in a procession around the city amid loud cries of cheering people and ear-splitting sounds of musical instruments, which produced huge noise and great uproar in the city. Servants decorated my son with all sorts of ornaments of gold and silver, diamonds and other gems. His entire body was covered with precious stones shining like moons,

\section{Hikayat Indraputra (Mulyadi, 1983, pp. 150-3, 195-198) ${ }^{16}$}

The King Syahsian began the uninterrupted wedding celebration to give the princess $[\ldots]$ in marriage to Indraputra. [...] And Indraputra settled down in the city, and he enjoyed feasts with all the princes and played percussion instruments [together with] them.

When forty days and forty nights had passed, [the princess] was carried around the city in a procession seven times. Musical instruments such as drums, gongs, flutes and ceremonial trumpets sounded deafeningly. Servants decorated the princess with ornaments of gold, bracelets, rings [...] and pendants of diamonds shining like stars. After that, they decorated the princess. She was seated on the seat covered with a piece of bright coloured cloth, and her countenance $[\ldots]$ was so radiant and dazzling that no one could see it clearly. 


\section{Malay version of The Tale of the Four Dervishes \\ (TFD, pp. 240-241)}

and the light of candles dimmed, because the radiance of his diamonds and gems eclipsed all other lights. Afterwards, he was seated in the seven-tiered wedding palanquin, and he looked so beautiful [and dazzling] that no one could see him clearly. Meanwhile, the procession with the princess carried in her palanquin approached the royal palace. [At that moment] the joyous cries and cheering of the king's counsellors, princes and common people became heard, and their noise was so loud that one could think that the doomsday had happened in the city. When the princess reached the palace, she was ushered into it and seated on the dais of the bridal couple. And the princess and my son were like the moon and the sun. The king, his grandees and myself approached and sat, facing the bride and the groom. Then the king rose and [was the first who] performed the ritual of feeding the newlyweds from his hands. After him the royal counsellors, grandees and myself rose from the seats, and each of us put a pinch of rice in the mouth of each newly-wed. When the ritual was over, the servants carried the bride and groom to their bedchamber. The next day, military chiefs and the common people placed [vessels with] water for the lustration on the ceremonial litters and carried the [vessels with] water in procession around the city, entertaining themselves, just like the day before. And when this [circumambulation] was over, the servants seated the princess and my son in the multi-tiered bathing pavilion, and the newly-weds performed the lustration.

\section{Hikayat Indraputra \\ (Mulyadi, 1983, pp. 150-153, 195-198)}

bright coloured cloth, and her

countenance $[\ldots]$ was so radiant and

dazzling that no one could see it clearly.

Servants decorated Indraputra with ornaments of gold studded with precious stones of all kinds [...] And Indraputra was seated in a palanquin [...]. And the servants carried this [unusual] palanquin in procession, and the palanquin was turning by itself [on its axis]. Then strings of pearls [with which the palanquin was decorated] began to ring and produce sounds like musical instruments [...] Meanwhile, Indraputra arrived at the palace of the King Syahsian. [...] And His Majesty seated him on the seat covered with bright coloured cloth at the right hand of the bride. And the countenance [of the princess] was unspeakably beautiful, shining and radiant and dazzling like the moon in its fourteenth night $[=$ the full moon] [...], whereas the countenance of Indraputra was [shining] like the sun. The servants placed [a platter of] wedding rice before Indraputra and, when the newly-weds had partaken of it, Indraputra took the princess in his arms and carried her to the bedchamber.

Three days later, the kings Raja Dewa Lela Mengerna and Nabat Rum Syah together with all the princes built a multi-tiered bathing pavilion in which Indraputra and the princess were to be lustrated. After that, Raja Dewa Lela Mengerna and Nabat Rum Syah properly arranged ritual litters, brought water for the lustration [...]. And servants carried those litters [with the vessels] of water in a procession around the city to the earsplitting sounds of musical instruments. And then, the servants lustrated Indraputra and the princess in the bathing pavilion. 
The beauty of the girl is described in the story of the third dervish from Bagh-o-bahar as follows:

[...] her face was like the moon, and her ringlets on both sides [of her head] hung loose; she had a smiling countenance; and she was dressed like a European, and with a most charming air; she was seated [on the throne] and looking forward

(Forbes, 1857, p. 254)

In the Malay translation, this description is substituted for the one well known to any reader of traditional Malay literature from fantastical adventure romances in prose and verse, for instance, from Hikayat Indraputra:

\begin{tabular}{|c|c|}
\hline $\begin{array}{l}\text { Malay version of The Tale of the Four } \\
\text { Dervishes (TFD, p. 201) }\end{array}$ & $\begin{array}{l}\text { Hikayat Indraputra } \\
\text { (Mulyadi, 1983, p. 108) }\end{array}$ \\
\hline $\begin{array}{l}\text { Her appearance was as if painted on a } \\
\text { picture, the colour [of her skin] was a blend } \\
\text { of white and yellow, her countenance was } \\
\text { oblong, her cheeks were like two halves } \\
\text { of a mango, her nose was like a bud of a } \\
\text { jasmine, her eyebrows were like curved } \\
\text { spurs [of a fighting cock], her eyes were } \\
\text { round, her teeth were [slightly] curved, } \\
\text { her lips were [red] like Chinese lipstick, } \\
\text { her hair was curly like palm blossom, her } \\
\text { temples were [a bit] protruding so that they } \\
\text { look more beautiful, and her clothes were } \\
\text { like those of English ladies. }\end{array}$ & $\begin{array}{l}\text { [Candra Lela Nurlela's] appearance was } \\
\text { extraordinary beautiful: }[\ldots] \text { her hair was } \\
\text { like moulded ringlets }[\ldots] \text {, her eyebrows } \\
\text { were like curved spurs [of a fighting cock], } \\
{[\ldots] \text { her eyes were like the morning star }[=} \\
\text { the planet Venus], her nose was like a bud } \\
\text { of a jasmine, }[\ldots] \text { her cheeks were like two } \\
\text { halves of a mango, her lips were [red] like } \\
\text { a betel-quid first torn, her teeth were like } \\
\text { seeds [seen through] a crack in the skin of } \\
\text { a pomegranate }[\ldots] \text {. }\end{array}$ \\
\hline
\end{tabular}

Typically, right in the next passage, Mahmud leaves the strategy of substitution and returns to the strategy of rendition, with its sometimes longwinded sentence-by-sentence paraphrasing close to the translation proper. In this manner, he, as if deliberately, shows the marked contrast between these strategies:

\begin{tabular}{|l|l|}
\hline $\begin{array}{l}\text { Bagh-o-bahar by Mir Amman } \\
\text { (Forbes, 1857, p. 254) }\end{array}$ & $\begin{array}{l}\text { Malay version of The Tale of the Four } \\
\text { Dervishes } \\
(\text { TFD, p. 201) }\end{array}$ \\
$\begin{array}{l}{[\ldots] \text { when I recovered, I got up, and went }} \\
\text { up to the angelic woman and saluted her; }\end{array}$ & $\begin{array}{l}\text { As soon as I saw this [beautiful] woman, I } \\
\text { approached her and greeted her respectfully. }\end{array}$ \\
\hline
\end{tabular}


Bagh-o-bahar by Mir Amman

(Forbes, 1857, p. 254)

she did not in the least return my salute, nor did she open her lips. I said, 'O lovely angel, in what religion is it right to be so proud, and not to return a salute.'
Malay version of The Tale of the Four Dervishes

(TFD, p. 201)

[However], she did not say a word in reply, perhaps [too proud] of her beauty. Then I said to her, 'O my lady princess, whose body is like a flower, why don't you reply to my greetings? Whose code of manners and which religion [allow you] to ignore a salute of people? [...].'

\section{THE OLD AND THE NEW IN THE LITERARY AESTHETICS OF THE MALAY VERSION OF THE TALE OF THE FOUR DERVISHES}

[These are] the most beautiful stories that should bring benefit to all God's servants.

(From the preface of the Malay version of The Tale of The Four Dervishes)

The ample use of the strategy of substitution may create the impression that Mahmud's translation contributes nothing to the descriptive aspects of traditional Malay literature. However, as two representative descriptive motifs of TFD show, this is not quite true. These motifs are the palace and the park or garden, which usually form a complex of sorts. ${ }^{17}$ Although in his descriptions of the palace-garden complex Mahmud largely proceeds from the substitution strategy, he applies this strategy not as strictly as in the descriptions of weddings. Let us turn, for example, to the palace and garden complex of the princess of Basra in Bagh-o-bahar, which the second dervish portrays as follows:

[...] then the female servant came to me and said, 'Come, the princess has sent for you.' I went along with her; she led me to the private apartment; the effect of the lights was such that the shab-i kadr was nothing to it. A masnad, covered with gold, was placed on rich carpets, with a pillow studded with jewels; over it an awning of brocade was stretched, with a fringe of pearls on [silver] poles studded with precious stones; and in front of the masnad artificial trees formed of various jewels, with flowers and leaves attached, [one would say they were nature's own production,] were erected in beds of gold.

(Forbes, 1857, p. 118) 
Mahmud's translation of this passage is a combination of the substitution and the rendition strategy, typical for his descriptions of this complex. However, the substitution strategy predominates, since the Malay counterpart of the Urdu passage is close enough to the earlier descriptions of palaces and gardens in Malay hikayat, with their stock formulas brought by the first wave of literary influence from Islamicate India. Here is a comparison of the passage from TFD and a few excerpts from those earlier hikayat.

\begin{tabular}{|c|c|}
\hline $\begin{array}{l}\text { At the sight of an unusually beautiful abode } \\
\text { of the princess, all the members of my body } \\
\text { weakened. For it seemed that the whole } \\
\text { house and everything that filled it were } \\
\text { made of precious stones. Therefore, no } \\
\text { doubt it could be called a House of Jewels, } \\
\text { especially if one added that the candles, } \\
\text { oil lamps, girandoles and lights lit it so } \\
\text { brightly, that no one could see [its decor] } \\
\text { clearly. Having entered into this abode, I } \\
\text { noticed and examined a very spacious dais } \\
\text { overlaid by carpets produced in the city of } \\
\text { Rum and by covers made of precious } \\
\text { camlet, scarlet broadcloth, rich fabric called } \\
\text { 'eyes of maidens', and velvet woven with } \\
\text { golden threads. [...] } \\
\text { There was a garden there also made of } \\
\text { gold and silver, with big vases [full of] } \\
\text { multifarious flowers of diamonds and other } \\
\text { precious stones: emerald, sapphires, gems } \\
\text { of many kinds and multicoloured veined } \\
\text { marble. All the flowers were made of these } \\
\text { stones. And I gazed at that garden that } \\
\text { verily did not look like a creation of human } \\
\text { beings, for only through the Omnipotence } \\
\text { of God could [its marvels] have appeared } \\
\text { [on earth]. }\end{array}$ & $\begin{array}{l}\text { Combination of traditional Malay } \\
\text { descriptive formulas from several } \\
\text { hikayat } \text { tr }^{2} \\
\text { [That palace] built of ivory and ebony rested } \\
\text { upon [the base of] marble [...]. And on the } \\
\text { top of it a magic stone shining extremely } \\
\text { brightly was fixed [...]. The first tier of the } \\
\text { palace was inlayed with opals, the second } \\
\text { tier with sapphires, [...] the fourth tier with } \\
\text { pearls, [...] the sixth tier with diamonds, } \\
\text { and the seventh tier with emeralds. The } \\
\text { candles, Chinese lanterns, girandoles, and } \\
\text { oil lamps kindled [everywhere] glimmered } \\
\text { so dazzlingly that no one could see them } \\
\text { clearly. And the palace was embellished } \\
\text { with carpets and covers [made of the cloth] } \\
\text { woven with golden threads and of precious } \\
\text { camlet, scarlet broadcloth, rich fabric called } \\
\text { 'eyes of maidens', and velvet. } \\
\text { Then [I] entered a garden [...], and [saw] } \\
\text { many big vases made of gold, and silver, } \\
\text { and a precious alloy of gold and copper } \\
\text { inlaid with jewels of various kinds. And } \\
\text { there was a tree in that garden, of which } \\
\text { the trunk was made of gold, and leaves } \\
\text { of turquoise, and flowers of emerald and } \\
\text { fruits of rubies. And I had a feeling that all } \\
\text { this was not a creation of humans, but the } \\
\text { mighty work of Allah Glorious and Most } \\
\text { High, the Lord of the Worlds. }\end{array}$ \\
\hline
\end{tabular}

And yet, the influence of the Urdu original is also perceivable in this rather typical Malay description. Turning to the classical hikayat of the late sixteenth to eighteenth centuries, it is difficult, if possible at all, to find a portrayal of a genuine "House [and park] of Jewels", in which every object 
is made of iridescent gems, their radiance reigning supreme over all and everything in the description. ${ }^{19}$

The rendering of TFD's descriptions of gardens and palaces, which stand halfway between the translation and the substitution strategy, also brings new options to Malay representations of this old descriptive motif. For instance, the image of "leaves similar to emeralds" is common in the Malay hikayat tradition. However, the exquisite comparison of leaves shining with raindrops to radiantly green emerald inlaid with pearls and diamonds is a novelty contributed by the Malay translation of Bagh-o-bahar:

[...] I looked at the leaves on the trees, and these leaves were similar to pieces of green emerald. And when raindrops fell on the leaves, they looked like pearls and diamonds set in those pieces of green emerald.

$$
(T F D, \text { p. } 50)^{20}
$$

Another example of descriptive novelties drawn from Mir Amman's version of TFD is a portrayal of the protagonist's reverential circumambulation of his beloved, like the flight of a nocturnal insect around a candle that irresistibly attracts it. And yet, the proverbial Persian-Urdu moth is transformed in this description into a Malay black beetle:

And I saw that the countenance of the princess looked like a candle burning in a Chinese lantern, around which a black beetle circles full of desire to fly into the flame of the candle. Beside myself, I stood up, entered the pavilion and [reverently] went around the princess, just like the beetle whom I have already mentioned. Then I approached the princess [...]

$$
\text { (TFD, p. 27). }{ }^{21}
$$

Finally, Mahmud bin Sayid Mu'alim's translation reproduces a description from the Urdu original that portrays how the protagonist's vision of the nocturnal garden changes as his melancholy in separation from the beloved gives way to the joy of his encounter with her. It is true that trysts of lovers in the moonlit garden are a commonplace in the earlier Malay hikayat. However, in this form, with a sudden transfiguration of the landscape, when the metaphoric "thorns of sufferings" are at last removed from the enamoured protagonist's eyes, this description is undoubtedly an innovative elaboration of the old descriptive motif: 
As I did not find the princess in the garden, the whole garden, with its blossoming trees, opened flowers and radiant moon that lit up all around, seemed to have turned into thorns that stuck into my eyes. [However,] in the midst of my [grievous] mood, the Lord [...] put a desire [to come into the garden] in the heart of my beloved, and she came. When I saw her countenance in the garden, my joy knew no bounds. [...] Only after that, the garden began to shine before my eyes, because the princess had appeared in it. And at this instant my vision became clear again, as if the thorns were removed from my eyes.

$(T F D, \text { p. } 26)^{22}$

\section{CONCLUSION}

The Malay version of TFD, which presents a rendering of Mir Amman's Bagh-o-bahar, is the earliest extant translation of a literary piece from Urdu into Malay. The work on the translation was accomplished in 1846 in Singapore by Mahmud bin Sayid Mu'alim, a Jawi Peranakan born in Malacca, with the help of his friend Rahman Khan. In his rendering of the Urdu classic, Mahmud successfully balances old features of the Malay love-and-adventure romance and new features, which he draws from Bagh$o$-bahar, his source text. In order to achieve this balance, Mahmud resorts to a combination of two strategies of translation in his target text. One of them is the strategy of substitution, oriented to the expectations of his Malay audience. The other is the strategy of rendition, which not infrequently allows him to enrich habitual narratives and descriptions with novel shades and tones of imagery, and/or uncommon use of it. Thus, the Malay versi on of TFD not only contributes to the beauty of emotionally active descriptions, the core of Malay literary aesthetics, but also sheds new light on how these descriptions were employed to embellish old or new plots, and may have been created in the earlier, lesser-documented period of literary influence from Islamicate India in traditional Malay literature.

\section{NOTES}

1 This article presents a considerably transformed and corrected version of my earlier paper entitled "The Story of Four Dervishes: the First Translation from Urdu in Traditional Malay Literature". That paper was published in electronic form in Jurnal e-Utama 2 (2009) issued by the Malay Language and Culture Department of the National Institute of Education of Singapore, Nanyang Technological University. I am most grateful to the Head of the Malay Language and Culture Department, Dr Hadijah Rahmat, for 
her kind permission to use that publication in the present article. While working on this article, I resorted to three translations of Bagh-o-bahar: the English translations by Forbes (1857) and Mohammed Zakir (2006) and the Russian translation by Zograf (1962b). The Forbes translation, not particularly smooth in style and rather archaic in vocabulary, served as the main text, since these features are not dissimilar to those of the Malay text under scrutiny. Two other renderings were consulted, when a clarification of particular sentences or passages in the Forbes translation were necessary. Unless stated otherwise, all the translations from Malay in this article are mine.

2 The term "Islamicate" was coined by Marshall Hodgson (1974, pp. 57-60), who distinguished between the term "Islam" (with its derivative Islamic), meaning a body of ritual texts and laws related to religious matters, and the term "Islamicate", implying the complex, diverse and multi-ethnic civilizations based on Islam across the entire Islamic world or, in other words, Islam in its civilizational aspect. The term "Islamicate" was applied to India in the influential book Beyond Turk and Hindu by Gilmartin and Lawrence (2000, pp. 2, 9-11). According to Kent (2013, p. 7), their understanding of this term refers to "those [Indian] kingdoms, where Persian and Turkish modes of governance and civilizational styles prevailed". Later, the term Islamicate with this meaning was shared by many Indologists. In the present article, the toponym India embraces the entire Indian subcontinent before its political division into India, Pakistan and Bangladesh.

3 For the original Malay text of this and all other epigraphs, see Appendix 1 to this article.

4 For these translations, see Braginsky and Suvorova, 2007, pp. 115-153.

5 The manuscript (henceforth MS) of the National Library of Singapore (= NLS) Q 11.4A/27 (call number 891.5523) contains a Malay translation of Qissa-ye char darvesh (rendered into Malay as Cetra empat orang fakir), the work known in Persian and Urdu versions. This MS numbers 270 pages with the pencil per-page pagination. The size of the page $31 \times 22 \mathrm{~cm}$; the size of the text $26 \times 17 \mathrm{~cm}$; 25 lines per page. Good European paper, thick and strong, with two watermarks: tre lune (three moons) and "VG". The MS is written in large naskh with some cursive features. Black ink. Phrases in Arabic, the words Allah, Qur'an and sometimes indicators of a new "paragraph" (sebermula, al-kisah, etc.) are written in red ink. The date of the text's composition is given by its translator Mahmud bin [Almarhum] Sayid Mu'alim bin Arsyad Marikan in the form of a chronogram as 8 Dhulhija $1262 \mathrm{AH}$ (26 November $1846 \mathrm{CE}$ ). On 10 Jumad alawwal 1263 AH (25 April 1847 CE) Mahmud's translation was copied by the scribe Ismail bin Ali. The place of both the translation and copying is Singapore. On the back of the front cover there is a sticker with another title of the work: Bunga Anggrek di Atas Pagar (An Orchid on the Fence). Neither the origin nor the relation of this title to the text (which mentions no orchids) is comprehensible. Just as in Mir Amman's composition, which is the source of the Malay translation, this strange title is probably connected with the chronogram. The latter contains the Arabic-Persian word sargh "grape-vine", or anggur in Malay. A later owner or user of the MS may have confused this word with the word anggrek (orchid), which, when written in Jawi, is quite similar in spelling. On the MS's flyleaf there is the stamp of Raffles Library and the inscription in English: "Four poor men. A Malay translation from the Persian. Done in Singapore. This manuscript is dated 1791 A.D. Added to Raffles library, 1923". The origin of the 


\section{MALAY LITERATURE VOLUME 30 NUMBER 1 JUNE 2017}

intriguing, although wrong, date, 1791, is unknown. Some features of the MS indicate that it may have been intended for the lithographic press. For the earlier descriptions of this MS, see Haji Wan Ali, 1993:18-19, and Chan Fook Weng, 2008, p. 217.

6 For Amir Khusrau Dehlavi, see, for instance, Muhammad Wahid, 1935; Zoe Ansari, 1975; Schimmel, 2016. The formula Maka berkata sahib al-hikayat Syaikh Amir Khusrau ("The storyteller, Sheikh Amir Khusrau, narrates ...") occurs in TFD, pp. 24, 64, 70, $71,152,160,161,198,216,251$, etc.

7 Cf., however, the different position of Muhammad Salim-Ur-Rahman, 1998, pp. 161-162. According to the catalogue of the former India Office, $T F D$ "popularly ascribed to Amir Khusrau [...] is also considered to be by Muhammad Wahid but is probably by an unknown author of the early Mughal period" (see Catalogue of Persian Manuscripts, 2016).

8 The illustrated Persian manuscript of TFD from the former India Office collection (see Prints and Drawings, 2016, Add.8917) confirms this exchange of the positions and adds some more details contrasting Persian versions with their Urdu counterparts. For instance, the prince from the second story (in the Persian sequence) is in love with a princess from among the peris, while in Urdu versions he is in love with the princess of Farang. In the same second story (in the Persian sequence), there appears the prince who carries with him his dead wife's body in a coffin, while in Urdu versions the prince's foster-brother carries with him the coffin with the murdered prince's body.

9 Cf., however, Muhammad Sadiq, 1964, pp. 210-211.

10 For the place and significance of this episode from the tale of the second dervish in the overall composition of The Tale of The Four Dervishes, see its summary below.

11 This is how "Abdul Haq introduces each of these passages, exemplary in his view (references, in curly brackets, to the passages under scrutiny in the Forbes translation and TFD are added; V.B.): "In one place he has told of the result of frivolous expenditure. Just look at the words in which he has depicted poverty! [...] \{Forbes, 1857, p. 32, cf. TFD, pp. 14-15\}. The language and conversation of every occasion and situation he has written just as it ought to be. For example: 'O child, may the arrow of my grief [...] \{Forbes, 1857, p. 253, cf. TFD, p. 200\}. Or look at the prayer and conversation of an old woman [...] \{Forbes, 1857, p. 270, cf. TFD, p. 217\}. Or, for example, look at the description of the games and amusements of the Vazir's daughter [...] \{Forbes, 1857, p. 158, cf. TFD, p. 133\}" (Pritchett, 2005, pp. 17-20).

12 All page numbers refer to the pagination of TFD (MS Q 11.4A/27).

13 For instance, the princess of Basra addresses Allah with a long speech, which includes a prose elaboration of Mir Amman's verse:

\begin{tabular}{|l|l|}
\hline $\begin{array}{l}\text { Bagh-o-bahar by Mir Amman } \\
\text { (Forbes, 1857, p. 185) }\end{array}$ & $\begin{array}{l}\text { Malay version of The Tale of the Four Dervishes } \\
\text { (TFD, p. 97) } \\
\text { When Your slave [=I] had no teeth, You, O Lord, } \\
\text { gave her milk as her sustenance; and when Your } \\
\text { When thou hast given teeth, wilt thou not grant } \\
\text { food! }\end{array}$ \\
$\begin{array}{l}\text { slave grew up, You gave teeth to her mouth, so } \\
\text { that she would eat food gifted by Your grace. [...] } \\
\text { Now your slave, who hopes for You, O Lord, } \\
\text { [believes] that thanks to You she may receive } \\
\text { her livelihood. }\end{array}$ \\
\hline
\end{tabular}


14 The italicized part of the paragraph corresponds to one line of poetry in Mir Amman's text: "When the wealth comes gratuitously, the heart has no mercy on it".

15 "Instrumental sciences" (ilmu alat) is a body of disciplines which included Arabic language and a number of sciences auxiliary in relation to theology (the doctrine of tauhid, or God's unity).

16 The following description is constructed from excerpts from the portrayal of Indraputra's marriages to the Princess Mengindera Seri Bulan (pp.150-3) and the Princess Mengindera Sari (= Seri) Bunga (pp. 195-198).

17 On this complex in Urdu literature, see (Dekhtyar [Suvorova], 1979, pp. 50-58).

19 The following text is made up of descriptive formulas that occur in Hikayat Indraputra (Mulyadi, 1983, pp. 68, 79, 107, 148, 203), Hikayat Isma Yatim (Hikayat Isma, 1910, pp. 20, 24, 28, 58) and Hikayat Syah Mardan (Zabedah Abdullah, 2000, p. 48). As in the earlier hikayat tradition, the formulas in question are used in a number of descriptions. Besides, they are not necessarily applied to the same objects in those hikayat and in our text.

20 The motif of the "house of gems" or house of jewels also shows the intimate connection of beauty, didacticism and spirituality is in $T F D$, and in traditional Malay literature as a whole. The point is that the princess of Basra, who owns the "house of gems", is unreservedly faithful to God. Expelled from her father's palace because of this faithfulness, she addresses Him in a moving prayer, and God gives her that inexhaustible reserve of jewels from which her "house of gems" is built. It is not accidental either that none other than precious stones appear in this story. Their radiance (in contrast to their rough nature) is symbolically associated with the Divine Principle (cf. Braginsky, 2011:9-10), and thus they shine as a reflection of both the True Source of the princess's riches and her faithfulness to God as the reason for her becoming rich.

21 In Bagh-o-bahar we find the following presentation of this image: "As the raindrops fell on the fresh green leaves of the trees, one might say they were like pearls set in pieces of emerald [...]" (Forbes, 1857, p. 78).

22 In Bagh-o-bahar: "After strolling for a few minutes about the garden, she sat down in the alcove on a richly-embroidered masnad. I ran, and like the moth that flutters around the candle, offered my life as a sacrifice to her [...]" (Forbes, 1857, p. 60).

23 In Bagh-o-bahar: "[...] when I beheld the roses, I thought of the beautiful rose-like angel, and when I gazed on the bright moon, I recollected her moon-like face. All these delightful scenes without her were so many thorns in my eyes. At last God made her heart favourable to me. After a little while that lovely fair one entered from the [garden] door adorned like the full moon [...] By her coming, the beauties of that garden, and the joy of my heart, revived" (Forbes, 1857, p. 38). 


\section{REFERENCES}

Braginsky, V. and A. Suvorova. (2007). A new wave of Indian inspiration: translations from Urdu in Malay traditional literature and theatre. Indonesia and the Malay World 36-104.

Braginsky, V.. (2011). The sight of multi-coloured radiance: lighting effects in Malay love-and-adventure narratives and the sufi concept of visuality. Rainbows of Malay Literature and beyond; festschrift in honour of Professor Md. Salleh. Yaapar. L. Sinha (ed.). Penang: Universiti Sains Malaysia Press.

Brakel, L.F., 1975. The Hikayat Muhammad Hanafyyah: A medieval Muslim-Malay romance. The Hague: Nijhoff.

Catalogue of Persian Manuscripts in India Office. Qissa-i Chahar Darvish, 2016, http://www.bl.uk/catalogues/indiaofficeselectpd/FullDisplay. aspx?RecordId=015-000019754 (accessed 1 October 2016).

Chan Fook Weng. (2008). Catalogue of rare materials in Lee Kong Chian reference library. Singapore: National Library Board.

Dekhtyar (Suvorova), A.A. (1979). Problemy poetiki Dastanov Urdu (The issues of poetics in Urdu Dastans). Moscow: Nauka.

Farooqi, M.A. (2003). The secret of letters: chronograms in Urdu literary culture. Edebiyat 13-2, 2003.

Faruqi, Sh.M. and F.W. Pritchett. (1994). A date list for Urdu literature - A work in progress. Annual of Urdu Studies 9, 1994.

Forbes, D. (transl.). (1857). Bagh-o-Bahar, or Tales of The Four Darweshes. Translated from Hindustani of Mir Amman of Dihli by Duncan Forbes. London: W.H. Allen.

Gilmartin, D. and B.B. Lawrence, D. Gilmartin and B.B. Lawrence (eds.). (2000). Introduction. Beyond Turk and Hindu: rethinking religious identities in Islamicate South Asia. Gainesville: University Press of Florida.

Grierson, J.A. (1903). A bibliography of Western Hindi, including Hindostani. Bombay: Education Society Press.

Haji Wan Ali Wan Mamat. (1993). Katalog manuskrip Melayu di Singapura. Kuala Lumpur: Perpustakaan Negara Malaysia.

Hikayat Isma Yatim. (1910). Singapore: Educational Service of the Straits Settlements. Hodgson, M.G.S. (1974). The venture of Islam: conscience and history in a world civilization. Chicago: University of Chicago Press.

Kent, E.F., E.F. Kent and T.R. Kassam (eds.) (2013). Introduction. Lines in water: religious boundaries in South Asia. Syracuse, N.Y.: Syracuse University Press.

Marre, A. (transl.). (1878). Makota Radja-Radja, ou la Couronne des Rois / par Bokhari de Djohore. Paris: Maisonneueve et Cie.

Mohammed Zakir (transl.). (2006). Mir Amman, a tale of four dervishes. London: Penguin Books.

Muhammad Sadiq. (1964). A history of Urdu literature. London: Oxford University Press. 
VLADIMIR BRAGINSKY

Muhammad Salim-Ur-Rahman. (1998). Classics Revisited. Annual of Urdu Studies, 13, $1 \mathrm{http}: / /$ www.urdustudies.com/pdf/13/12salimClassics.pdf (accessed 1 October 2016).

Muhammad Wahid Mirza. (1935). The life and works of Amir Khusrau. Calcutta: Baptist Mission Press.

Mulyadi, Rujiati S.B. (ed.). (1983). Hikayat Indraputra: a Malay romance. Dordrecht: Foris.

Prints and Drawings. (2016). Add.8917, www.bl.uk/catalogues/indiaofficeselectpd/ PrintandDraw.aspx (shelfmark Add.8917) (accessed 12 October 2016).

Pritchett, F.W. (transl.). (2005). Muqaddimah-e Murattib [Editor's Introduction] by Maulvi “Abdul Haq, http://www.columbia.edu/itc/mealac/pritchett/00urdu/ baghobahar/intro_abdulhaq.html (accessed 1 October 2016).

Schimmel, A. (2016). Amir Kosrow Dehlavi. Encyclopaedia Iranica online. http:// www.iranica.com/newsite/authors/ index.isc (accessed 2 October 2016).

Zabedah Abdullah (ed.). (2000). Hikayat Syah Mardan. Kuala Lumpur: Dewan Bahasa dan Pustaka.

Zoe Ansari (ed.). (1975. Life, Times and Works of Amir Khusrau Dehlavi. New Delhi: National Amir Khusrau Society.

Zograf, G.A. (1962a). Predisloviye (Introduction). Mir Amman, Sad i Vesna (The garden and spring). Translated from Urdu into Russian by G.A. Zograf. Moscow: Izdatel'stvo Vostochnoy Literatury.

Zograf, G.A. (transl.). (1962b). Mir Amman, Sad i Vesna (The garden and spring). Moscow: Izdatel'stvo Vostochnoy Literatury.

Received: 17 December 2016

Accepted: 21 February 2017 


\title{
THE MALAY ORIGINAL OF THE PREFACE OF TFD
}

\author{
Bismillah al-Rahman al Rahim
}

[...] Segala puji bagi Allah yang menunjuki kita dengan iman dan Islam, [...] dan dipeliharakan kita daripada kufur dan kalam durhaka. [...] Dan kita pohonkan pada-Nya bahwa ditetapkan iman pada hati kita dan pada lidah kita. [...] Dan rahmat Allah atas penghulu kita Saidina Muhammad yang membawa kita ke negeri yang sejahtera, [...] dengan rahmat yang senantiasa daripada Raja yang mengetahui segala yang ghaib-ghaib, [...] dan atas segala keluarganya dan segala taulannya yang suci mereka itu daripada segala suci.

Amma ba'ad hadha al-qissah bi'l-lughat Farsi 'Car Darvesh', yakni cetera-cetera daripada bahasa Parsi 'Empat orang fakir'. Adapun kemudian daripada itu, memuji Allah dan mengucap salawat akan Rasul-Nya, maka inilah kisah yang dipindahkan daripada bahasa Parsi kepada bahasa Melayu dan daripada segala cetera-cetera orang dahulu [...] dan daripada cetera-cetera segala auliya dan hukama [...] dan daripada segala cetera-cetera orang yang membelakangi dunia [dan] daripada cetera-cetera yang berbuat kebaktian di bumi dan di langit. [...] Dan dibahagikan dia atas lima kisah.

Maka kata seorang fakir bi 'l-dhanb wa'l-taqsir, iaitu Mahmud bin Sayid Mu'alim, anak Melaka, dan adalah pada zaman dan masa itu bahwa adalah hamba itu berniaga di dalam negeri Singapura. Maka datanglah seorang sahabatku, peranakan orang Hindustan, dan namanya Rahman Khan. Maka datanglah ia membawa sebuah kitab kisah ini yang terlalu indah-indah sekali akan ceteranya itu. Maka setelah sudah hamba mendengar akan cetera itu, maka datanglah berahi hatiku dan asyik akan cetera itu. Maka hamba minta tolong aku kepadanya dengan seboleh-boleh minta(?) pindahkan daripada bahasa Parsi ke dalam bahasa Melayu. Setelah ia melihat kelu[h]an berahiku itu, maka datanglah rahim kepada hatinya, maka ia pun minta tolong pula kepada Tuhan [.?.], maka datanglah himmat hatinya, maka menolonglah ia akan membuatkan serta memindahkan daripada bahasa Parsi kepada bahasa Melayu.

Sebermula adalah pada tahun 'bisaragh'dan dualapan haribulan Dalhija [sic].

Maka adalah fakir itu tiada mengetahui bahasa Melayu istimewa lughat Melayu Jawah [= Jawi] sekali tiada mengetahuinya, sebab karena tiada paham dan tiada berilmu barang sedikit sekali. Maka berpeganglah aku dengan bersungguh-sungguh kepada Tuhanku serta berkat Nabiku Saidina Muhammad. Maka kubuatkanlah kitab ini dengan tiada sepertinya ini. Maka kuuraikan juga dengan seboleh-bolehnya, maka jadilah perkataan yang pendek menjadi panjang dan yang panjang menjadi pendek, sebab tiada kutahu loghat Melayu. Hai ikhwanku sekalian yang melihat atau yang mendengar dan yang membaca hikayatku ini, jikalau tia [da] munasabah kepada syara' Nabi kita Saidina Muhammad, melainkan aku harap-harap sangat-sangat kepada sekalian saudaraku yang tahu lughat Parsi dan yang tahu lughat Melayu mengubahkan perkataan itu supaya memberi manfaat pada sekalian hamba Allah yang membaca kisahku ini serta mengambil ibaratnya yang sahih. Wa Allahu 'alam!

\section{Note of the copyist (TFD:270)}

Setelah (?) selesai daripada menyurat hikayat ini di dalam negeri Singapura [Dar?] al-salam kepada sepuluh haribulan Jumad al-awal, yaum al-Ithnain, pada hijrat seribu dua ratus enam puluh tiga tahun. Hak Mahmud ibn al-Marhum Sayid Mu'alim bin Arsyad Marikan. Yang menyuratnya al-kerani Ismail bin Ali. 


\section{THE MALAY ORIGINAL OF QUOTATIONS FROM TFD}

\section{p. 000}

Maka adalah pada suatu hari sekalian orang di dalam negeri itu kecil besar dan tua(h) muda(h) sekalian berjalan keluar negeri itu. Adalah di luar negeri [illegible word] itu adalah suatu padang besar sekali. Maka pergilah orang itu sekalian kepada padang itu, berkampung serta bersaf-saf beratur. Dan adalah di situ raja negeri itu dan orang besarbesarnya sekali adalah hadir di-situ. Maka hamba pun adalah serta orang banyak itu. Maka datanglah seorang muda(h) daripada pihak hutan negeri itu. Maka adalah rupanya itu sahib al-jamal dan berbusa-busa pula mulutnya, terlalu baik sekali parasnya. Adalah umurnya itu tiga-empatbelas tahun umurnya. Dan rupanya seperti anak-anakan raja besar jua dan adalah ia kendaraan di atas lembu seekor kuning warnanya. Maka datanglah ia kepada sekalian khalq [Arb. the people] Allah yang banyak di padang itu. Setelah ia sampai, maka turunlah ia dari atas kendaraannya itu, duduk ke tanah seraya memegang tali lembunya itu dan sebelah tangan memegang pedang bercabut dan ada pula pegang suatu benda-hamba tiadalah ketahui. Maka dipanggilnya seorang budak, umurnya enam-tujuh tahun budak itu. [lacuna] Maka budak itu bawalah kepada orang banyak itu, ditunjukkan kepada sekalian orang yang ada di padang itu. Setelah orang itu sekalian melihat akan benda yang dibawa oleh budak itu, maka menangislah sekalian orang yang melihat itu. Setelah habislah sudah ditunjukkan oleh budak itu, maka pergilah ia kembali kepada orang muda(h) yang naik di atas lembu itu. Setelah budak itu datang, maka dijinjangnya oleh orang muda itu dengan pedangnya yang dipegangnya itu kepada leher budak itu, maka budak itupun matilah. Maka orang muda(h) itu pula naiklah di atas kendaraannya itu, lalu ia berjalanlah pergi, dari mana datangnya itu di situlah kembali. Maka sekalian orang banyak yang di padang itu sekaliannya kembalilah ke dalam negeri.

\section{p. 000}

Ya 'abd Allah (ertinya, hai hamba Allah), dengan sebaik-baik pendengaran tuan-tuan dengarkanlah / dan memberi telinga dengan sebaik-baik pendengaran. / Tuan, dengarkan cetera hamba akan hal fakir ini bercetera-cetera yang hamba mendapat dan hamba mendengar dan melihat. / Cetera seperti kepala ke bawah dan kaki ke atas yang hamba dapat yang hamba ceterakan ini.

Maka sekarang mahulah tuan-tuan mendengar akan cetera fakir ini, dengan bersungguhsungguh hamba bercetera daripada permulaannya hingga datang kepada kesudahannya. I Maka katanya adalah hal hamba ini seperti seorang jua mendapat penyakit yang besar sekali yang tiada dapat ditadbirkan (yakni tiada dapat dibicarakan oleh seorang juga). I Jika hakim dan hukama atau tabib yang besar-besar sekali pun kehendaki hendak mengobati akan penyakit hamba, tiadalah boleh sekali-sekali. / Karena hamba itu cela $(h)$ hati hamba yang hamba menurutkan itu, maka menjadilah penyakit besar sekali.

Adalah kening tuan seperti taji dibentuk; kenapakah gerangan tuan tiada datang kemari? / Dan sebab kerana tuanlah, maka hamba bertapa empat puluh hari. 


\section{MALAY LITERATURE VOLUME 30 NUMBER 1 JUNE 2017}

\section{p.000}

Maka rupanya yang seperti bulan itu menjadi kelamlah serta masam, dan karut dahinya dengan marahnya, maka katanya tuan puteri: 'Baiklah, jikalau begitu selama ini engkau menaruh asyikkah kepadaku ini. Adalah seperti misal dikata orang-orang tua: 'Adapun kodok tempatnya di dalam air.' Maka sekarang kudengar katamu itu adalah seperti kodok berkata ini duduk di dalam air, menjadi lemas konon'.

Engkau makan nasi di kebun itu dan engkau basuh tangan di sini.

\section{p. 000}

Setelah berapa lamanya hamba duduk di atas itu, maka datanglah pula tahunnya dan bulannya dan harinya dan saatnya sesal di atas kepala hamba ini, maka datanglah orang muda-muda belia terlalu banyak daripada pihak orang tiada bermalu dan tiada bersopan dan fitnah dan hasad sekalian. Daripada akal yang jahat datanglah ia bersahabat kepada hamba. Maka hamba pun mengikutlah akan nasihatnya yang keji-keji, maka hamba pun mengikutlah kepadanya dan hamba pun termasuklah di dalam pukatnya yang celaka itu. Sebermula diajarnya oleh orang celaka itu kepada hamba seraya katanya: 'Hai tuan yang baik paras dan muda(h) belia(h), apakah gunanya semua [an illegible word] itu dan harta yang sebanyak itu jikalau tiada tuan menyukakan tatkala muda(h) ini. Jika tuan nanti apalah gunanya lagi? Adapun yang baik kepada hamba sekalian, baik juga [pada] tuan. Berlajar minum khamr dan minuman-minuman yang memberi asyik berahi serta dengan mabuk-mabuk selasih. Itulah yang baik kepada hamba sekalian. Dan kedua, maka mahulah tuan minum janganlah tuan seorang diri. Menjadi tiada mendapat rasanya dan lezatnya sekali-sekali. Baikjuga tuan mengambil anak-anakan perempuan yang muda $(h)$-muda $(h)$ serta dengan elok parasnya. Tatakala itu barulah tuan mendapat rasanya dan lezatnya minuman sekalian itu. ' Setelah hamba mendengar, maka terbukalah hati hambamu dan sukaria dengan terlalu amat sangat. Maka hamba pun kabulkanlah, maka hamba pun mengikutlah pengajaran dan nasihat sekalian itu. Maka menjadilah lupa sekalian perbuatan dan perniagaan pun tiadalah teringat sekali-sekali. Maka hamba pun belanjakanlah harta yang ditinggalkan oleh ayahanda baginda itu yang tiada terhisab itu tiadalah dengan kadarnya atau kira-kira bagaimana garuk harta ini datangnya kepada hamba. Maka bagaimana datangnya, demikianlah perginya dengan tiada boleh dapat terhisab lagi dan hingganya melainkan dengan belanja jua seperti orang tiada sedarkan diri adanya.

Maka hamba pun ngapallah menurut akan perkataan syaitan yang berpengajaran manusia jua. Bukannya syaitan yang dijadikan Tuhan kita, mengajarkan pengajaran syaitan manusia itu. Dan cukuplah kepada hamba pengajarannya syaitan manusia itu. Dan tiada kasihan kepada hak yang ditinggalkan oleh ayahanda baginda itu, dengan sia-sia jua perginya. Karena apa sebabnya? Bukannya hamba penatkan ia, ta' hamba mencarikan harta itu. Jikalau sekiranya hamba yang empunya pencarian, niscaya hamba tiadalah berani kerjakan [demikian].

Adapun sekarang, pada sangka hamba, tatkala hamba belanjakan harta itu, jikalau seperti khazanah Karun sekalipun habis juga hamba belanjakan dengan sekejap mata juga. Maka berkata sahib al-hikayat: 'Dengarkan olehmu nasihat saudaramu, dengan sebolehbolehnya ambillah olehmu ibarat ini, pakaikan kepada akalmu dan hatimu. Hai saudaraku tua dan muda, dengarkan olehmu cetera telah hilang harta daripada tangannya itu'. 


\section{p.000, ftn.00}

Maka tiadalah ada bergigi, maka Tuhanku memberi pula akan hambamu rezeki daripada susu jua, dan telah besarlah hambamu maka Tuhanku kurniakan gigi kepada mulut hambamu makanlah rezekiMu daripada ni'matMu sekalian. [...] Sekarang haraplah akan hambamu kepada Tuhanku dengan Kamu mudah-mudahan jua hambaMu mendapat rezeki Tuhanku jua.

\section{p.000}

Setelah diperanakkan baginda kepada hamba, maka dipeliharalah baginda dengan beberapa kesusahan serta dengan inang pengasu[ $h]$ dan dayang-dayang daripada anak orang yang besar-besar jua. Maka setelah sampailah umur hamba tujuh tahun, maka disuruh baginda mengajar mengaji Qur'an. Tiada berapa lama mengaji Our'an telah tamatlah sudah dengan karunia Allah Ta'ala dan baginda menyuruh pula berlajar mengaji kitab-kitab dan ilmu alat. Dengan tolong Tuhan yang menjadikan sarwa sekalian alam, dengan segera jua hamba dapatlah ilmu yang hamba pelajari itu dengan mudahnya jua. Telah sampailah usianya hamba empat belas tahun, maka hamba pun duduklah dengan bersuka-sukaan kepada sahabat hamba, iaitu anak menteri hulubalang serta anak orang kaya-kaya.

\section{p.000}

Maka raja pun bertitah kepada menteri hulubalang hendak memulai pekerjaan kahwin anak raja, seperti adat kahwin anak raja yang besar-besar empat puluh hari empat puluh malam dengan bersuka-sukaan, makan minum, pencak tari, masing-masing dengan halnya bersuka-sukaan jua. Setelah genaplah empat puluh hari empat puluh malam, maka anak raja pun diarakkan oranglah berkeliling negeri dengan terlalulah ramai permainannya sekali dan bunyi-bunyian pun terlalu ramai dan gegak-gempita di dalam negeri itu sebab permainan belaka. Maka anak hamba pun diriasi oranglah dengan sekalian hiasan pakaian daripada emas perak dan intan manikam. Penuhlah sekali tubuhnya dengan permata menjadi teranglah seperti bulan dan cahaya api pun hilanglah sudah, sebab karena cahaya intan manikam menjadi kelamlah sekalian cahaya yang lain-lain. Maka didudukkan oranglah di atas pelaminan tujuh tingkat, dan rupanya terlalulah elok sekali, tiadalah boleh dipandang nyata. Maka anak raja berarak pun dekatlah sudah istana raja, maka berbunyilah sekalian tempik dan sorak sekalian menteri hulubalang dan rakyat, menjadi seperti kiamatlah negeri itu. Maka anak raja pun sampailah ke istana, lalu dibawa masuklah duduk ke atas pelaminan itu. Maka menjadilah anak raja dan anak aku seperti bulan dan matahari. Maka raja dan orang besar-besar dan aku pun datanglah mengadap kepada penganten kedua-dua itu. Maka raja pun bangunlah membuat suap-suapan dan sekalian menteri dan orang besar-besar dan aku pun bangunlah membuat suap-suapan. [Se]telah sudahlah, maka keduanya pun dibawa masuk oranglah kepada tempat peraduan. Setelah keesokan hari, maka segala hulubalang dan rakyat sekalian pun mengaraklah air mandi berkeliling negeri dengan permainan pun jua. Setelah sudah, anak raja dan anak aku didudukkan oranglah di atas panca persada seraya bersiram.

\section{p. 000}

Adalah rupanya itu seperti gambar ditulis dan warnanya putih kuning dan mukanya bujur dan pipinya seperti pauh dilayang dan hidungnya seperti kuntum melur dan keningnya seperti taji dibentuk dan matanya bundar dan giginya lentik dan bibirnya merah seperti gincu Cina dan rambutnya ikal seperti mayang mengurai dan pelipisannya pun terulur dipandang manis dan pakaiannya seperti perempuan Inggeris. 


\section{MALAY LITERATURE VOLUME 30 NUMBER 1 JUNE 2017}

\section{p.000}

Setelah sudah hamba lihat belaka, maka hamba hampirilah kepada perempuan itu serta dengan beberapa hormat dan salam. Maka tiadalah ia menyahut salam hamba itu sekalisekali perempuan ini, sebab rupanyakah? Maka kata hamba: 'Hai tuan puteri badan seperti bunga, mengapakah tuan tiada mau menyahut salam hamba? Kepada adat siapakah itu dan pada agama manakah itu tiada mau menjawab salam orang? [...].'

\section{p.000}

Maka [...] lemah sudah anggota hambamu melihat terlalu indah-indah sekalian mahaligai tuan puteri itu. Adalah seperti sekalian ruma[h] itu dan isinya sekalian serasa sudah menjadi manikam sekalian di ruma[h] itu dan boleh dikatakan rumah manikam semua pula bertambah dian pelita dan kandil setulup gemerlapan tiadalah dapat ditentang nyata. Maka setelah hamba sampai ke dalam mahaligai itu, maka hamba amat-amati adalah suatu majlis terlalu besar sekali. Adalah hamparannya daripada katifah buatan negeri Rum dan beberapa pula katifah daripada suf sakhlat 'ain al-banat dan makhmal zari b-t-ng (?) emas belaka. [...] [Dan] adalah suatu taman dibuatnya daripada emas perak jua, dan adalah jambangan dan pohon bunga-bunga(h)an daripada intan manikam jauhar zamrud nilam pualam puspa ragam panca logam dibuatnya pohon bunga-bunga(h)an. [...] Sekalian itu perbuatan dari batu-batu jawahir belaka. Maka hamba melihat dengan sebenar-benarnya pada pihak taman itu adalah seperti bukannya perbuatan manusia sekali-sekali hanyalah kudrat Ilahi jua datangnya itu sekalian.

\section{p. 000}

[...] maka hamba melihat pada daun pohon sekalian itu, adalah daun itu seperti batu zamrud yang hijau. Dan jatuh titik-titik hujan di atas daun itu, maka menjadilah seperti disendikan mutiara dan manikam di atas batu zamrud yang hijau itu.

\section{p. 000}

Maka tatkala itu hamba melihat rupanya tuan puteri itu seperti kandil tanglung terpasang, maka ada pula kumbang berkeliling-keliling hendak masuk kepada api itu. Maka hamba pun bangkitlah tiada sedarkan dirinya, lalu hamba naik ke atas balai itu, seraya berkeliling kepada tuan puteri serupa tabi'at hamba tatkala itu samalah bagaimana kumbang yang hamba sebutkan dahulu itu. Maka hamba pun hampir juga kepada tuan puteri itu [...].

\section{p. 000}

Maka sebab tiada tuan puteri itu di sini, maka menjadilah sekalian pandangan pada mata hamba kebun itu dan pohon-pohon bunga dan bunganya yang kembang itu dan bulan yang terang dan menerang itu menjadi seperti durilah menyocok kepada mata hamba. Antara yang demikian itu. Maka Tuhan [...] telah dimasukkan gerak kepada hati mahbu[b] hamba itu, maka ia pun datanglah kepada kebun itu. Maka setelah hamba melihat rupa mahbu[b] hamba itu datang ke dalam taman itu, maka hamba pun sukalah yang maha sangat. [...] Maka tatkala itu pada mata hamba taman itu baharulah berseri-seri karena sebab tuan puteri ada melihat itu. Maka hamba pun barulah terang mata hamba yang seperti dicocok duri itu. 